\title{
A SHORT RESEARCH IN DANISH CARDINAL AND ORDINAL NUMERALS ON INDO-EUROPEAN BACKGROUND
}

\author{
BŁAŻEJ GARCZYŃSKI \\ Adam Mickiewicz University in Poznań
}

ABSTRACT. The article focuses on the Danish numerals 1-1000. It presents their Proto-Indo-European, Proto-Germanic, Old Danish and present forms whilst providing additional information on their development and corresponding numerals in other European languages. It focuses primarily on the vigesimal counting system, whose traces can be found in Danish, and which is the source of some unique forms unseen in other languages. Therefore, special attention is paid to the numerals of the series 50-90. Though these appear to be unique and exotic, the article shows that they are not to be perceived as an anomaly but rather a different path of development within the language Moreover, a brief explanation of the origins of the vigesimal system in Danish is provided. Also, several units of measurement showing traces of the vigesimal, duodecimal and sexagesimal systems are discussed. Finally, language reforms aimed at changing the numeral forms will be shortly portrayed.

\section{INTRODUCTION}

Danish is, as are its Scandinavian and Germanic relatives, a descendant of Proto-Indo-European (PIE). Therefore, its numeral forms are chiefly inherited from PIE. In the article, Danish cardinal and ordinal numbers will first be investigated by shortly describing the PIE counting system and the possibility of its reconstruction. Further on, several counting systems that have different numeral bases which can be found among European languages will be distinguished. Among these, the origin and usage of the decimal and the vigesimal systems will be described. 
Next, Danish cardinal and ordinal numerals will be analysed by providing some of the forms that they acquired during their development. Since the following article was not meant to be a thorough historical investigation on the development of Danish numbers with each phase carefully examined, but rather a glance at their present forms supplemented by a brief historical background, the listed modern forms will be accompanied by only several major forms that the numeral acquired in a specific phase. Apart from this description, special attention will be paid to the numerals 50,60,70, 80 and 90, and their origin and spread in the language will be discussed. This particular focus is due to the system that lies behind them and their unique forms unseen in other modern European or even Scandinavian languages. The system, however unique and hard to learn, is nothing abnormal, but represents merely a language development that took place alongside the "mainstream" evolution of other, not only Scandinavian, languages. Moreover, numeral constructions with halv- and their corresponding forms in other languages will be presented.

The last part of the article will analyse several units of measurement that show traces of the vigesimal, duodecimal and sexagesimal (the last two being now relics in IE languages) counting systems. Additionally, the article will describe official language reforms that changed (or attempted to change) the numeral system in Danish, Norwegian and Faroese.

\section{BRIEF INFORMATION ON INDO-EUROPEAN NUMERALS}

\subsection{THE RECONSTRUCTION OF PIE NUMERALS.}

Beekes (1995:212) writes that "the numerals of PIE can be reconstructed down to the last detail". Numerals as a class are very unique: "No class of words [...] has been so persistent as the numerals in retaining their inherited words. [T] he IE words for 'one' to 'ten' have persisted everywhere with only slight changes other than phonetic; likewise the IE word for "hundred"' (Buck 1949:936 cited by Winter 1992:11). This, on one hand, is not to be taken for granted, because numerals are often borrowed. On the other hand, it is only partially true, since the numerals in the PIE counting system form a series and influence each other within it. The development of the numerals is therefore complicated and can be described only in general terms (cf. Beekes 1995:212). But even though Gvozdanović (1992:11f.) notes that the range of numerals from 'one' to 'ten' did undergo some changes in all the Indo-European languages, and that they still pose some reconstructional problems, she still admits that they all can be traced down to a common PIE form. Additionally, Mańczak (1985:351) states that higher numerals within the series 20-90, that is 
60-90, may be subject to more developmental alternations due to their rarer usage than the lower numerals of the series, that is 20-50, which preserved more conservative forms due to more frequent usage.

The above said applies mainly to cardinals, the reconstruction of ordinals is namely far more difficult. They cannot be reconstructed with precision due to a large variety of their forms in descendant languages (cf. Fortson 2004:132).

\subsection{COUNTING SYSTEMS}

Each Indo-European language possesses specific building blocks called numeral bases that enable constructing numbers of higher series. According to the numeral bases following systems can be distinguished (Gvozdanović 1992:8f.):

- the system based on 'five', i.e. the quinary system, in Welsh, and with sporadic evidence in Old Indian;

- the system based on 'ten', i.e. the decimal system, which is the main system in Indo-European languages;

- the system based on 'twenty'. i.e. the vigesimal system, in Iranian, Indo-Aryan, Albanian, Celtic, Romance, North Germanic, and sporadically as borrowed in Slavic;

- $\quad$ the system based on 'hundred', in Modern Indo-Aryan [...].

Two of the listed systems function in Danish. The usage of the decimal system is no surprise, as it is the dominating system found in every IE language, but the vigesimal ${ }^{1}$ system is also used to some extent. In the following section, I will have a closer look at both of these systems.

\subsection{THE DECIMAL AND VIGESIMAL COUNTING SYSTEM}

As noted before, it is not surprising that the decimal system appears in Danish, because it is the main system that all the IE daughter languages have adopted. This way of counting may result from the fact that in prehistory counting was first achieved by using body parts - e.g. the fingers. This is reflected in the etymology of certain numbers, notably in the names of the PIE 'ten' and 'hundred', both containing the root $* d k$ also seen in the word for 'finger' (Lat. digitus, cognate to Eng. toe). Moreover, all the decades and the numerals for 'hundred' are based on

${ }^{1}$ The terms are derived, respectively, from Lat. decimus and vīcēsimus meaning 'tenth' and 'twentieth'. 
'ten'. But although the Indo-European numeral system was without doubt decimal (there are some late innovations in form of duodecimal numerals such as OHG zëhanzo 'tenty' or O.E. hundandlaftig '110', but they can still be derived from a decimal system) many instances of the vigesimal counting system can also be found (cf. Blažek 1999:332).

The non-PIE 'twenty' based system, the vigesimal system, can be found in exactly three Indo-European language branches: Romance, Celtic and Germanic (cf. Vennemann \& Noel Aziz Hanna 2003:598f.) One of the most notable examples is modern French, where the number ' 80 ' is based on '20': quatre-vingts $4 \times 20=80$, whereas the number 90 applies both the decimal and the vigesimal system: quatre-vingts-dix $(4 \times 20)+10=90$ (the form vingt is also pronounced slightly different when it appears in the multiplicational forms; cf. Hurford 1975:99ff.). French numbers are quite irregular, so it seems to be more plausible to perceive them not as one but two combined systems. It also needs to be mentioned that similar cases may be found in Old French (vint e dis $20+10=30$ or deus vins $2 \times 20=40$ ).

The decimal system is without doubt of PIE origin, but how to explain the vigesimal system? It has been attempted to account for its existence with several arguments: 1) it is the outcome of a spontaneous and independent innovation; 2) it is a foreign import; 3) it is of a substratal origin. It is quite relevant to mention that the vigesimal system correlates in a considerably high degree with its presence in non-Indo-European languages, for which the system is characteristic, such as modern Georgian or Gaulish. The latter has been therefore proposed as the origin of the system in French. In general, it is usually Celtic that is perceived as the source of the vigesimal system in Western European languages, but Vennemann \& Noel Aziz Hanna (cf. 2003:537f.) argue that the vigesimal system could not have come from Celtic, since it cannot be found in Old Celtic. He suggests that since "an estimated 30 per cent of the ProtoGermanic vocabulary has no or no reliable etymology, research in the field of non-Indo-European influence is particularly promising" (ibid. 2003:xiii). Hence, he claims that the origin of the system as well in Celtic as in French can only go back to Vasconic.

"Vasconic languages, i.e. languages related to present-day Basque, were spoken in Europe north of the Pyrenees and the Alps for several millennia after the last ice-age" (ibid. 2003:vii). The influence of Vasconic can be seen not only in toponyms but is also suggested to have been exerted on the way of counting. Therefore, traces of vigesimality can be found in some of the European languages like German, English and Insular Celtic. In Ger. Schock now means 'sixty', but it used to mean 'twenty'. In English the inherited numerals 60 and 80 were replaced in the eleventh century by, respectively, threescore and fourscore. These forms contained 
the element - score $^{2}$ of Scandinavian origin (cf. Mańczak 1985:351), derived from O.E. scoru and from O.N. skor. Its usage is explained by Online Etymology Dictionary as follows:

score (n.) late O.E. scoru "twenty," from O.N. skor "mark, tally," also, in Icelandic, "twenty," from P.Gmc. *skura-, from PIE root*(s)ker- "to cut" (cf. O.E. sceran; see shear). The connecting notion is perhaps counting large numbers (of sheep, etc.) with a notch in a stick for each 20. [...] In Old French, "twenty" (vint) or a multiple of it could be used as a base, e.g. vint et doze ("32"), dous vinz et $\operatorname{diz}(" 50 ") .[\ldots]$

Let the fact that the British pound was made of 20 shilling up to the year 1971 be another example of a 20-based system (cf. Vennemann \& Noel Aziz Hanna 2003:530f.).

Modern Germanic languages and also Proto-Germanic were decimal, though traces of six- or twelve-based system can also be found, e.g. in Ger. Dutzend 'dozen'. These rare forms apply though only to some special domains such as counting hours of the day, the minutes of an hour, the number of degrees on the compass etc. (see also 3.6. in this article).

The Basque way of counting is also vigesimal and thus supports the idea of substratal influence of Vasconic on Indo-European (cf. ibid. xix f.). The traces of the vigesimal system may be found in Danish as well, but unfortunately its existence in the language is difficult to explain. It is most often believed that it was a spontaneous innovation appearing without any preceding Middle Age forms or language contacts (cf. Eliasson 2006:92), but it is sometimes claimed that it may have been influenced by the Norman's contacts with the British Isles (where the system was primarily borrowed into Celtic from the substratal languages of the Isles) or Northern France. It is also worth mentioning that the Normans brought the vigesimal system into Sicily and Southern Italy (cf. Blažek 1999:332ff.).

The vigesimal system in Danish appears first in preserved written records around the year 1300 in Jutland and spreads to the whole of Denmark around 1400 (cf. Eliasson 2006:91). Its development is summarized by Brøndum-Nielsen (Brøndum-Nielsen 1950:207f., cited by Eliasson 2006:92):

${ }^{2}$ Cf. the usage of score in The Gettysburg Address by Abraham Lincoln from 1863 referring to the year 1776, which is perceived as the beginning of the American nationhood: "Four score and seven years ago (...)" (87 years) or in "I Have a Dream" speech by Martin Luther King from 1963 referring to Abraham Lincoln himself: "Five score years ago (...)" (100 years). 
In the written sources, the score counting system surfaces for the first time in the manuscript of the Danish text of the Flensborg municipal law (from about 1300) with the forms fiyrsin tiughæ $[4 \times 20$, i.e., 80$] \ldots$, half fæmpt sin tiygh $[(1 / 25$ th $) \times 20$, i.e., $90] . .$. , whereas, at approximately the same time, East Danish manuscripts... use the decade forms siutyugh ..., siu tiugh, siu tiughæ [70]..., following the same decade system as thrætiughu, firitiughu [30, 40]..., and so forth. But already our oldest diplomas in Danish - East Danish as well as West Danish - use throughout the score system in the numerals $50-90$ : fire $\sin ($ ni) tiugho $[4 \times 20$, i.e., 80$]$, half thrithiæ sinnæ tiughu $[(1 / 23$ rd $) \times 20$, i.e., 50$]$, etc.

A separate analysis could be performed in order to track the first appearances and the spread of the vigesimal numeral forms. It may prove difficult though, since the tendency in the oldest available sources is to write larger numerals above twenty with numbers only thus rendering their pronunciation impossible. It can be stated with a considerable degree of certainty that the process of adopting the vigesimal system began in Western Denmark and spread eastwards (cf. Karker 1959:11f.). The earliest examples can be found in the Flensborg manuscript (Flensborghåndskrift) from around 1300. Since 1400 first instances of the vigesimal numerals can be found in sources from Eastern Denmark (Consolation of the Soul (Sjalens Trøst), Lund Chronicle (Lundekrøniken)).

\section{THE ANALYSIS OF DANISH CARDINAL}

\section{AND ORDINAL NUMERALS}

Languages developed over time and it caused significant changes in their grammar, e.g. English lost gender, while Danish reduced it from three to two. These changes have also influenced the form of the numerals in each of the languages (cf. Ross \& Berns 1992:557). As already mentioned in the beginning of the article, etymological account of each form will not be discussed in detail, thus omitting most of the stages in the development of a numeral and focusing only on these three forms (if a numeral allows it): the PIE root, the Proto-Germanic and the Old Danish forms. Unless noted otherwise, the PIE cardinal forms are taken from Beekes (1995:214f.), the PIE ordinals, P.Gmc. and the O.D. forms are taken from Ross \& Berns (1992). O.D. displays a large variety of dialectical forms, but they will not be quoted here - they can be found in the work of Brøndum-Nielsen and the Dansk Etymologisk Ordbog (see References).

Furthermore, the older and now obsolete inflectional forms (accusative, dative feminine, neuter etc.) of the numerals will not be named, unless they provide the base of the contemporary numeral. When it is possible, corresponding forms found in other contemporary IndoEuropean languages will be compared with them. 
In the list below a brief description of the following numerals will be provided: the series $1-20,30,40,50,60,70,80,90,100$ and 1000. The list consists of a cardinal number followed by its corresponding ordinal. As far as ordinal numerals are concerned, there is a general rule that can be applied: Danish and some other languages have developed suffixes that allow them to construct ordinals from the cardinal forms, e.g. in OHG the suffix for forming ordinals from decades was -ôsto (as in sëhszug $\rightarrow$ sëhszugôsto 'sixty' $\rightarrow$ 'sixtieth'). A similar suffix, -asti, is found in later Icelandic (as in sextíu $\rightarrow$ sextugasti 'sixty' $\rightarrow$ 'sixtieth', with the -tugrepresenting the decadic element).

In all later West Germanic languages, with the exception of English, the suffixes -de and -te are used. In Modern Norwegian the suffix -ande is applied in Nynorsk whereas -ende is the suffix used in Bokmål. The Danish form was -undi (from P.Gmc. *-andi) and these forms most definitely influenced the M.E. -ende $e^{3}$. It is important to note that there are no old forms for ordinals meaning 'hundred' and 'thousand' (cf. Ross \& Berns 1992:622ff.). In French we find -ième deriving from Lat. -imus (as in primus, decimus etc.), Polish applies the suffix -ty for all the numerals higher than 3, Russian uses the suffix $-y j(-b i u ̆)$ or $-o j(-o u)$.

\subsection{NUMERALS OF THE SERIES 1-10}

- $\quad \boldsymbol{e n} / \boldsymbol{e t}^{4}$ 'one': no single PIE form can be reconstructed for 'one'. At least two roots of the concept existed: the most widely represented one is *oi- with various suffixations such as *oi-no- (as in Lat. unus, Goth. ains), *oi-ko- etc ${ }^{5}$. The Danish form is derived from the PIE *Hoi(H)nos, P.Gmc. *aenalō, O.D. én (though many dialectal forms may be found as well) and corresponds to the Eng. one and Ger. eins, ein ${ }^{6}$. The other roots were $*_{s e / o m-}$ and $*$ sem- and apart from representing the number 'one' they also expressed similarity. The root can therefore be found in such present-day forms as Eng. same, Dan. samme or Pol. [ten] sam (cf. Gamkrelidze/Ivanov 1995:740f.; Fortson 2004:131; Jagodziński 2008);

\footnotetext{
${ }^{3}$ The English suffix forming numerals $-t h$ derives from a more standard suffix applied in M.E., namely -epe from O.E. seofopa 'seventh' or aehtopa 'eighth'. During its development it lost the final $-e$ and then the medial $-e$ - with only $-p$ remaining. Unlike the standard suffix -epe, the -ende form can only be found in teens and sporadically in decades and 'seventh' up to 'tenth'. (cf. Gvozdanović 1992:623).

${ }^{4}$ Also written én/ét in order to distinguish them from the same looking indefinite articles for, respectively, the common and the neuter gender.

${ }^{5}$ For a comprehensive list of the suffixations see Gamkrelidze \& Ivanov (1995:740ff).

${ }^{6}$ The numeral corresponds to the English indefinite articles a/an that are derived from O.E. an meaning 'one', 'lone'. It can also be found amongst others in Dutch een (één), French un/une and Italian un/una.
} 
- $\quad f ø r s t e$ 'first': the numeral does not come from 'one' but is rather a word meaning 'front most', 'fore', 'foremost' and is usually derived from PIE *prh $3^{-}$with various extension stems (cf. Fortson 2004:132). A few forms of 'first' may be distinguished among IE languages, but let us concentrate on the Danish path only. The O.D. form was fyrstarlfyrsti (cf. Ross \& Berns 1992:625) derived from P.Gmc. superlative form of for (cf. Becker-Christensen 1999). Compare Ger. erste (from OHG furisto, cf. Ger. Fürst 'prince') and Dut. eerst(e) (both forms can also be derived from OHG superlative subtype êristo that results in Ger. ehe(r) Dut. eer meaning 'before, earlier'), Pol. pierwszy, Rus. pervyj (nервый) (from OCS priv; cf. Jagodziński 2008);

- $\quad$ to 'two': from PIE *duoh ${ }_{1}$ or an even earlier form *du, via P.Gmc. *twāi, *twā and O.D. thē (cf. Ross \& Berns 1992:562; Becker-Christensen 1999; Jagodziński 2008). Compare Ger. zwei, Dut. twee, Fr. deux, Pol. dwa, Rus. dva (два);

- anden, andet 'second' (the forms are used for, respectively, the common and the neuter gender): basically, no form of 'second' can be reconstructed in PIE due to the fact that daughter languages typically use expressions meaning 'other' or 'following', e.g. Lat. secundus means exactly 'following' (cf. Fortson 2004:132; Beekes 1995:216). The Danish form is accounted for in BeckerChristensen (1999) in a similar manner: " $[\cdots]$ akkusativ maskulinum sing. af ældre middeldansk annær $\leftarrow$ fællesgermansk *anaraz $\leftarrow$ indoeuropæisk *anteros [...]" with *anteros meaning 'the other from the two'. The O.D. form was annar and annan (cf. Ross \& Berns 1992:625). Compare Ger. andere, Dut. ander, Fr. autre. It. altro.

As we can see, the words for 'first' and 'second' are suppletives forms semantically not related to the cardinal numeral (cf. BeckerChristensen 1999). The same can be observed in Pol. drugi which replaced wtóry, which is still present in Rus. vtoroj (второй), and probably derives from PIE * witero- 'the one leading further' (cf. Jagodziński 2008).

It is also worth having a closer look at 'both', since its development is quite similar to 'two': nominative masculine P.Gmc. Бae (cf. *twae), genitive P.Gmc. நōjō via O.D. baggia to Dan. begge 'both' (cf. Ross \& Berns 1992:571). Cf. Ger. and Dut. beide, Pol. oboje, obydwa, Rus. obe (óбe).

- $\quad$ tre 'three': There are several suggestions that the numeral 'three' may have been influenced by 'two'. The PIE form *treies is hard to account for, but the stem ter- or -tor- appears in many words signifying a pair, e.g. IE *poter - māter 'father' - 'mother', so it may be that 'three' was basically 'two plus one' (cf. Jagodziński 2008). Compare also OEN *prēm from *prim + dative twèm that results in O.D. thrēm (cf. Ross \& Berns 1992:578). The development of the numeral: "fællesgermansk *prīz $\leftarrow$ indoeuropæisk *treies [...]" (BeckerChristensen 1999), the O.D. form being thrī. Compare Eng. three, Ger. drei, Dut. drie, Fr. trois, It. tre, Pol. trzy, Rus. tri (mpu).

- $\quad$ tredje 'third': PIE *tretjó-, P.Gmc. pridjan/ōn-, O.D. thrithia (cf. Ross \& Berns 1992:626);

- $\quad$ fire 'four': the numeral is based on the PIE * $k^{w} e t u \bar{o} r$-. The numeral is then further

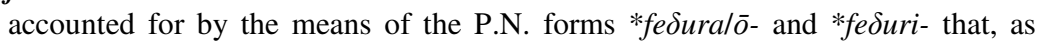


a result of sound changes, became O.D. fiōrir (nominative masculine form) and Dan. fire (cf. Ross \& Berns 1992:579f.). Compare Ger. and Dut. vier, Fr. quatre, It. quattro, Pol. cztery, Rus. četyre (чemblpe);

- fjerde 'fourth': PIE *petwúrto/ā- $\rightarrow$ P.Gmc. *feđupran/ōn-, O.D. fiarthi and fiarpa (Ross \& Berns 1992:627);

- $\quad f e m$ 'five': it is worth mentioning that the numeral is strongly connected with the word 'fist' (Ger. Faust, Pol. pięść; cf. Jagodziński 2008). The forms are: PIE ${ }^{*}$ penk ${ }^{w} e$ via P.Gmc. *fimf $\rightarrow{ }^{*}$ fimm and O.D. feem $\rightarrow$ făm (Ross \& Berns 1992:585f.). Compare Ger. fünf, Dut. vijf, Pol. pięć, Rus. pjat' (nяmb);

- femte 'fifth': P.Gmc. *fimftan/ōn-, O.D. farmtalfarmte (cf. Ross \& Berns 1992:628f.);

- seks 'six': PIE *(s)uéks, P.Gmc. *sexs, O.D. sax/sex (cf. Ross \& Berns 1992:585). Compare Ger. sechs, Dut. zes, Fr. six, It. sei, Pol. sześć, Rus. šest' (uecmb);

- $\quad$ sjette 'sixth': PIE *sekto/ā-, P.Gmc. sextan/ōn-. O.D. shows several forms (for a full list cf. Ross \& Berns 1992:628): saxte, satti, satta, sette (...);

- $\quad s y v$ 'seven': PIE *séptm, P.Gmc. *sebun, O.D. siū (cf. Ross \& Berns 1992:586). Compare Ger. sieben, Dut. zeven, Fr. sept, It. sette, Pol, siedem, Rus. sem' (семь);

- syvende 'seventh': PIE *sepmoto/ā-, P.Gmc. *sebunpan/ōn-, O.D. siūndi (cf. Ross \& Berns 1992:629);

- otte 'eight': PIE * $h_{3} e k t e h_{3}$, P.Gmc. *axtau, O.D. ätta (cf. Ross \& Berns 1992:588). Compare Ger. and Dut. acht, Fr. huit, It. otto, Pol. osiem, Rus. vosem' (восемь);

- $\quad$ ottende 'eighth': PIE *oktốto/ā-, P.Gmc. axtốpan/ōn-, O.D. àttundi (cf. Ross \& Berns 1992:629f.);

- $\quad n i$ 'nine': *(h $\left.h_{1}\right)$ néun, P.Gmc. *newun, O.D. nī (Ross \& Berns 1992:589); Compare Ger. neun, Dut. negen, Fr. neuf, It. nove. The Pol. dziewięc and the Rus. devjat' (девять) are explained in the following manner (cf. Jagodziński 2008): the initial $\mathrm{n}$ - was replaced by $\mathrm{d}-$ as a result of the $\mathrm{d}-\mathrm{n}<\mathrm{n}-\mathrm{n}$ dissimilation and probably under the influence of the following numeral 'ten' dziesięć/desjat' (десять);

- $\quad$ niende 'ninth': PIE newṇto/ā-, P.Gmc. newunpan/ōn-, O.D. nīunda (cf. Ross \& Berns 1992:630);

- $\quad \boldsymbol{t} i$ 'ten': descending from the PIE *dékmt probably derived from *de- or *-dwe 'two' and *kjm-, *kjem- 'hand', thus two hands = ten fingers. Via Germanic P.Gmc. *te $\chi u n$ and O.D. $t \bar{\imath}$ (Ross \& Berns 1992:590f.). Compare Ger. zehn, Dut. tien, Fr. dix, It. dieci, Pol. dziesięć, Rus. desjat' (десять);

- tiende 'tenth': PIE *deḱmto/ā-, P.Gmc. *texundan/ōn-, *tezunpan/ōn-, O.D. *tiūndi $\rightarrow$ tiunce (cf. Ross \& Berns 1992:631f.).

"Ten" and "tenth" require some additional information. The ordinal number tiende underwent substantivization and began to mean 'tithe'. In Dan. tiende and in Ger. zehnte mean 'tenth' as well as 'tithe'. Also the Fr. dime or dime, It. decima (from Lat. decimal), Pol. dziesięcina, Rus. desjatina (десятина) reflect this. Moreover, 'ten' is used as a suffix to create the numerals of the series 13-19: the rule is that the suffix is attached to a cardinal number. There are two exceptions to this rule though - Gothic, e.g. fimftataíhunda 'fifteenth' and OHG., e.g. 
drittozëhanto 'thirteenth' - both of them form the ordinals by attaching the suffix to an ordinal number (cf. Ross \& Berns 1992:633).

\subsection{NUMERALS OF THE SERIES 11-19}

This time there will be no PIE forms given, because it is simply not possible to reconstruct them - they probably were never firmly established. This numeral series was usually formed without any fixed order. They could be connected by conjunctions or prepositions, e.g. Lat. decem et duo (duodecim). In the series, the Germanic and the Baltic numbers 11 and 12 are exceptional - they are based on the P.Gmc. verb *leik $k^{w}$ - or *leip- 'to leave' that expresses the amount over ten (cf. Blažek 1999:332). The verb can be found in its O.N. descendant lifna, Dan. levne and Eng. leave.

The Polish and the Russian numerals of this series are constructed in a similar manner, namely by adding -naście/-nádcat' (-надиать) 'over ten' (literally 'onto ten') to the cardinal number (cf. Jagodziński 2008).

- Elleve 'eleven': the literal meaning of the reconstructed form is 'one over ten' - it consisted namely of the numeral en 'one' and the above-mentioned verb (cf. Becker-Christensen 1999); probably from P.Gmc. *ainalib via O.D. aellivu, allefue, elløfua (...) (Ross \& Berns 1992:593f.). Compare Ger. and Dut. elf;

- ellevte 'eleventh': P.Gmc. *aina-liftan/ōn-, O.D. allifta, allipte (Ross \& Berns 1992:633f.)

- tolv 'twelve': the Proto-Germanic form of the numeral was *twalib-, it consisted thus of the form *twāi- 'two' and *lib- 'rest', so it meant 'two over ten' (cf. Becker-Christensen 1999); O.D. form was tolf (cf. Ross \& Berns 1992:596). Compare: Ger. zwölf, Dut. twaalf;

- tolvte 'twelfth': P.Gmc. *twa-liftan/ōn-, O.D. tolfte. (cf. Ross \& Berns 1992:634).

The Danish numerals of the series 13-19 are formed by adding -ten (which, of course, means 'ten' and is derived from the Germanic *texun) to a cardinal number preceding it $^{7}$. Some form alternations may occur in the cardinal number. Corresponding ordinals are formed by adding $-d e$ to the cardinal (e.g. tretten $\rightarrow$ trettende 'thirteen' $\rightarrow$ 'thirteenth') - due to their regularity they will be not listed here (they can be found together with their O.D. forms in Ross \& Berns 1992:635-637) These numerals are:

- tretten 'thirteen': P.Gmc. *prīz, O.D. thræetắn (cf. Ross \& Berns 1992:597). Compare Germ. dreizehn, Dut. dertien;

- fjorten 'fourteen': O.D. fiōrtắn, fiǒrtắn (cf. Ross \& Berns 1992:599). Compare Germ. vierzehn, Dut. veertien;

${ }^{7}$ The same rule is applied, amongst others, by German (-zehn, e.g. dreizehn 'thirteen') and Dutch (-tien, e.g. zestien 'sixteen'). 
- femten 'fifteen': O.D. famtắn (cf. Ross \& Berns 1992:599). Compare Germ. fünfzehn, Dut. vijftien;

- $\quad$ seksten $^{8}$ 'sixteen': O.D. sicextă̄n (cf. Ross \& Berns 1992:601). Compare Germ. sechzehn, Dut. zestien;

- $\quad$ sytten 'seventeen': O.D. siūtān (cf. Ross \& Berns 1992:601). Compare Germ. siebzehn, Dut. zeventien;

- $\quad$ atten 'eighteen': O.D. *āttan (cf. Ross \& Berns 1992:601f.). Compare Germ. achtzehn, Dut. achttien;

- nitten 'nineteen": O.D. nītān (cf. Ross \& Berns 1992:602). Compare Germ. neunzehn, Dut. negentien.

\subsection{THE DECADES $20-40$}

Before these numerals will be discussed there are a few words that need to be said about forming ordinals with '-tieth'. "Formally, many of the Proto-Germanic prototypes are identical with two of those given under 'tenth', namely *texundan/ōn- and *tezunpan/ōn" (Ross \& Berns 1992:637). These shifted into O.D. *-tegundi, *-tegonde (Noreen 1923: § 94; Brøndum-Nielsen 1950-1957: § 96 cited by Ross \& Berns 1992:637f.). Since this formation is general, only O.D. forms will be given while discussing ordinals of this section.

- tyve 'twenty': the reconstructed PIE 'twenty' is *duidkmti which is a simplified version of the dual *duih $h_{1}-d k_{m}^{\prime} t \bar{t}-i h_{1}$ 'two-tens' (cf. Fortson 2004:131). Blažek (1999:332) suggests that the decades of the series 30-90 were constructed on a basis of a general and probably inherited pattern: "N $(=3,4, \ldots, 9) \mathrm{x} * d k$ kont'decad' + coll. $*_{-} H_{2}$ or pl. $*_{-s .}$." The same model is also found in Germanic and Balto-Slavic, e.g. Got. twai-tigjus, O.I. tuttugu, OCS. dŭadesęti (cf. Gamkrelidze \& Ivanov 1995:744f.). The Scandinavian forms are difficult to explain, though. Ross \& Berns (1992:604) argues that if the O.I. form were correspondent to the Gothic one, it should not be fossilized. The O.S. form tiughu is also difficult to account for - there are namely no reasons why a word that originally meant 'ten' would suddenly shift its meaning to 'twenty'. The matter is quite intricate and need not be analysed here, so it will suffice to say that the O.D. forms correspond to the O.S (tiughu, tyugho, ...) and that these forms can also be found in the '-ty' suffix as in -tiughu, -tiuwa, -tygha (eventually, the second form began to be used as 'twenty'). The complete explanation can be found in Ross \& Berns (1992:604ff.);

- tyvende 'twentieth': O.D. tiugende, tiuende, tiwende (cf. Ross \& Berns 1992:638).

\footnotetext{
${ }^{8}$ It is worth noticing that this numeral is pronounced [' sajsdən] unlike Swedish, whilst Norwegian has both pronunciations.
} 
There are a few other major and minor formations in IE languages that allow us to construct the decades of the series 30-90. Ross \& Berns (1992:607) distinguishes six subdivisions of the Scandinavian languages according the '-ty' formations that they apply: "(A1) Icel. tighir, etc.; (A2) O.S. -tiughu; (A3) O.S. -tiugh; (A4) O.S. -tighi; (A5) O.S. -tiughi; (A6) O.I. -tugu; (A7) O.N. -tigu; (A8) OIcel. -togo." A3 is not distinctive in O.D., because it may have blended with A2, whereas the existence of A6 is doubtful. I will use the A1-A8 as references for the forms existing in O.D. while discussing 30 and 40 :

- $\quad$ tredive 'thirty': PIE *trih ${ }_{2} d k$ komth $h_{2}$; the Danish forms are various and complex depending on the formation they apply. They can be found in Brøndum-Nielsen (1950-1957: § 547C.2) and apply the formations A1, A2, A3, A5 and A6;

- tredivte 'thirtieth': O.D. thratiughanda, thraediwghende (...; cf. Ross \& Berns 1992:639);

- fyrretyve/fyrre ${ }^{9}$ 'forty': PIE $* k^{w}$ eturdkomth $_{2}$; the numeral is a truncation of its underlying form fyrretyve 'four tens' (the form -tyve is not to be mistaken for 20 - it is derived from the O.N. tigr meaning 10; cf. Becker-Christensen 1999). Following formations are applied: A2, A3, A4, A6 (cf. Ross \& Berns 1992:614f.), but there are also the attested forms thuswartywghae and tysucertiugh that belong to the G-type formation (see 3.4. below);

- fyrretyvende/fyrrende 'fourtieth': O.D. føretiughende, føretiwende (cf. Ross \& Berns 1992:640).

\subsection{THE DECADES 50-90}

Before the PIE (given only for cardinals) and O.D. forms of these numerals will be discussed it has to be mentioned that there is a quite uncommon '-ty' formation characteristic for Old Danish. Ross \& Berns (1992:612) enumerates four main types of the first element in this formation (the second form is always 'twenty' in the forms A2, A3 or A6): a cardinal, an ordinal, 'twice' or 'thrice' or a part of sin 'time'. All the variations and combinations would simply be too numerous to be listed here, therefore only some examples will be given without pointing to the represented type. Brøndum-Nielsen (1950-1957): § 547 n. 3.) compiles a complete list of them and names them G-type formations.

Each of the numerals, both cardinal and ordinal, has two forms: a long one and a truncated one. The numerals in the following list there are untruncated, because it easier to see the resemblance to their earlier forms. The truncated ones will be given further on:

\footnotetext{
${ }^{9}$ The first form of the cardinal is rather archaic and has been practically replaced by the second.
} 
- halvtredsindstyve 'fifty': PIE *penkwedkomth ${ }_{2}$; apart from the major formations A2, A3, A4 O.D. displays variations of the G-form, e.g. halfftrediesynnontyughe (cf. Ross \& Berns 1992:616f.);

- halvtredsindstyvende 'fiftieth': O.D. G-type forms halffuetrydiesynnetywende, halftredyasinztyuenna (cf. Ross \& Berns 1992:640f.);

- tresindstyve 'sixty': PIE *ueksdkomth ${ }_{2}$; O.D. applies the A2, A3 and A4 formation; a few examples of the G-type forms are thrysinstiwo, thrysinstiwe, thrysinztiwe (cf. Ross \& Berns 1992:616f.);

- tresindstyvende 'sixtieth': O.D. thrysinstywandhe, trysinztywenne (cf. Ross \& Berns 1992:640f.);

- halvfjerdsindstyve 'seventy': PIE *septmdkomth ${ }_{2}$; O.D. shows the formations A2, A3, A4 and G-type, e.g. halffierdssinstiwge, halfficerdhasinztiwo (cf. Ross \& Berns 1992:618f.);

- halvfjerdsindstyvende 'seventieth': O.D. halffierdesinnetiughe (cf. Nielsen 1966:145);

- firsindstyve 'eighty': PIE $* h_{3} e k t h_{3} d k$ komth $h_{2}$; the A formation represented here is A4; among the G-type formations we find e.g. firasinstiwgho, firesinstiwgho (cf. Ross \& Berns 1992:618f.);

- firsindstyvende 'eightieth': O.D. firesinnetiughe (cf. Nielsen 1966:145);

- halvfemsindstyve 'ninety': PIE *h $h_{1}$ neundkomth ${ }_{2}$; O.D. displays the A4 form; among the G-type formations we have e.g. halffemtasintyughe, halffertessinstywa (cf. Ross \& Berns 1992:619);

- halvfemsindstyvende 'ninetieth': O.D. halfemtesintywende, halffamtasinatiwghende.

The present-day Danish numerals of the series of 50-90 require very special examination due to their uniqueness and the system that lies beneath them. When we look at them, we can clearly see that modern Danish inherited only these O.D. forms that belonged to the subtype G.

The forms of the numerals 50,60,70, 80 and 90 seem to be completely incomprehensible at first glance when their semantic structure is involved. Although they are indeed difficult to learn due to their complete dissimilarity to other languages, there is a hidden logic that lies behind them. In order to discover this logic we need to analyse where these forms derive from. Let us commence by saying that the forms listed above are already very old-fashioned and can be found rather rarely and that they have been replaced by their truncated forms. The truncated forms are mentioned as a part of the colloquial speech in grammar textbooks already around 1785, but they do not appear in dictionaries until 1860 (cf. Karker 1959:16ff.). These forms are constructed by simply removing the sindstyve:

$\begin{array}{lll}\text { halvtredsindstyve } & \rightarrow & \text { halvtreds } \\ \text { tresindstyve } & \rightarrow & \text { tres } \\ \text { halvfjerdsindstyve } & \rightarrow & \text { halvfjerds } \\ \text { firsindstyve } & \rightarrow & \text { firs } \\ \text { halvfemsindstyve } & \rightarrow & \text { halvfems }\end{array}$


As one can see, the forms that the contemporary numerals derive from are compounds consisting of one common element, i.e. -sindstyve. Before the forms preceding -sindstyve the question at hand: "what is -sindstyve?" will have to be answered. And the answer is quite simple: sinde (without the $-e$ in the compound forms) is an old Germanic form meaning 'multiplied by/times' whilst tyve is of course 'twenty'. This would solve the mystery of 60 and 80 , which are, respectively, 'three times twenty' and 'four times twenty'.

But what system lies behind the numerals 50, 70 and 90? These numerals require a bit more elaborate explanation. As can be observed, they all apply the prefix halv-followed by a somewhat alternated form of the ordinal numeral (tredje 'third', fjerde 'fourth' and femte 'fifth'). There used to exist cardinal numerals that consisted of the prefix halv-with an ordinal numeral following thereafter. Thus we had halvtredje, halvfjerde and halvfemte that simply meant 'the value of the ordinal numeral minus one half'. In accordance with this halvtredje would mean 'three minus half' so $2 \frac{1}{2}$, halvfjerde would mean 'four minus half' so $3 \frac{1}{2} 2$ etc. The forms halvtredje $=2^{1 / 1} 2$ and halvfjerde $=3 \frac{1}{2}$ are still existent, but definitely archaic (with one exception discussed further on), but they are an integral part of the numerals 50,70 and 90. With the given explanation in mind the following numerals are now simple to account for:

$\begin{array}{lll}\text { halvtredsindstyve } & \rightarrow & 2^{1 / 2} \text { times } 20=50 \\ \text { halvfjerdsindstyve } & \rightarrow & 3^{1 / 2} \text { times } 20=70 \\ \text { halvfemsindstyve } & \rightarrow & 4^{1 / 2} \text { times } 20=90\end{array}$

As mentioned before, the presented forms are now practically obsolete and have been replaced by their truncated counterparts, they are given in the table in order to show their underlying structure.

Moreover, the following pattern emerges: Danish uses multiplication of 10 for the numerals 20,30 and up to 40 , it switches then to multiplications of 20 , even though a quite complicated usage of fractions is necessary, although it is not uncommon to some other languages (cf. Hurford 1975:118).

Naturally, one does not have to know all this in order to master these numerals, especially if linguistically untrained learners are in question, but it definitely makes them more transparent.

Additionally, it is worth mentioning that these forms are not exclusively restricted to the Danish numeral system, but appear in another Scandinavian language, namely Faroese, which, though belonging to the West Scandinavian branch and sharing the majority of its features with Icelandic (thus rendering them both mutually intelligible), has been 
influenced by Danish due to its historical bonds with the Danish Kingdom - Danish was introduced as the official written language in 1540 and contributed to the Faroese syntax and vocabulary, including the numerals of the discussed series (cf. Magnussen 2009:252f.), whose forms are: hálvtrýsinstjúgu (50), trýsinstjúgu (60), hálvfjerðsinstjúgu (70), fýrsinstjúgu (80), hálvfemsinstjúgu (90). As in Danish, these numbers underwent truncation (hálvtrýss, trýss, hálvfjerðs, fýrs, hálvfems), and are now rather obsolete, but still occasionally used in writing or while speaking in order to add emphasis (cf. Lockwood 2002:64).

The strongest evidence for the underlying long forms is the formation of corresponding ordinal numerals that applies the long forms, though the long form ordinal numerals possess truncation counterparts that were recorded as correct in Retskrivningsordbogen in the year 1986. These are used mainly in everyday colloquial speech. The following table illustrates these relationships (cf. Hurford 1975:117f.):

\begin{tabular}{|l|l|l|}
\hline \multicolumn{1}{|c|}{$\begin{array}{c}\text { Cardinal } \\
\text { numeral }\end{array}$} & \multicolumn{2}{c|}{ Ordinal numeral } \\
\hline & \multicolumn{1}{|c|}{ Long form } & \multicolumn{1}{c|}{ Truncation form } \\
\cline { 2 - 3 } fyrre $(40)$ & fyrretyvende & fyrrende \\
halvtreds $(50)$ & halvtredsindstyvende & halvtredsende \\
tres $(60)$ & tresindstyvende & tressende \\
halvfjerds $(70)$ & halvfjerdsindstyvende & halvfjerdsende \\
firs $(80)$ & firsindstyvende & firsende \\
halvfems $(90)$ & halvfemsindstyvende & halvfemsende \\
\hline
\end{tabular}

(Fig 1.) Danish cardinal and ordinal numerals of the series 40-90

Although the rule does not apply to tredive $(30) \rightarrow$ tredivte $\left(30^{\text {th }}\right)$ it is worth to examine the form of this numeral for it is constructed by the same means as fyrre (40): the O.N. form was namely prír tiger the M.D. form was tredive, which is simply 'three tens'.

As mentioned before, the cardinal numerals consisting of halv-and an ordinal are archaic and rarely used with one important exception: halvanden that is 'one and a half'. Ordbog over det danske Sprog says the following: "halvanden [...] (glda. halfannan, ceda. halfændre [...], oldn. halfr annr, jf. ty. anderthalb".

Politikens Nudansk Ordbog med etymologi (1999) says that the usage of the numeral corresponds to expressions used for telling the time, e.g. halv to (literally 'half two') derived from an older form halvgåen to (literally 'half gone two'), which means that one half of a whole hour has passed since one o'clock. The usage of the form for telling the time is found not only in Danish but also in German (e.g. Es ist halb zwei 'It's half past one') or Polish (though only dialectically: pót dziewiatej 'half past eight' literally 'half of nine'; cf. Czesak 2005). Here we also deal with 
a reference to the German numerals anderthalb and dritthalb. Surprisingly, these German numerals basically share the same structure, though reversed and with a middle -t-, which can be explained in the following manner: anderthalb is derived from MHG. anderhalp. Grimm accounts for the appearance of the middle - $t$ - in the Deutsches Wörterbuch (1854) by saying that the ordinal character of the numeral led to copying of the middle -t- from ordinals (1854:314): “das der zählende auf die mitte oder hälfte von 1 zu 2 gelange, das andere (zweite) halb erreicht sei“".

Kluge (1999:283) says that this way of counting is common in all Germanic languages.

In Politikens Nudansk Ordbog med etymologi (1999) we find the following information under the entry 'halv': "fællesgermansk * $\chi a l \hbar a-$ 'halv' egl. 'overskåret' indoeuropæisk *kolpo-, *kelp-, *skelp- 'skære'; besl. m. latin scalpere 'snittemejsle"'.

Similar numerals forms (a compound of the word pót- 'half' and an ordinal) may also be found in Polish: póttora $\left(1 \frac{1}{2}\right)$, which still functions today, and now obsolete numerals póttrzecia $\left(2 \frac{1}{2}\right)$, pótczwarta $\left(3 \frac{1}{2}\right)$, pótpiatalpótpięta (41/2), pótdziesiąta $\left(9 \frac{1}{2}\right)$ or even higher ones such as pótczwartanaście (131/2). Pót- is derived from the PIE *(s)pel- meaning "to split, to tear apart, to rip off', so the basic meaning was that we "rip off" the half (pót) from the accompanying numeral (cf. Bańkowski 2000:752ff.; Boryś 2005:477). A similar concept can be found in the Germanic verb *leik ${ }^{w}$ - or *leip- (see 3.2.).

Russian has these forms as well: poltora (полтора; 11/2) and now obsolete pol' trét'ja/tret'i (поль третья/третьи; 21/2), pol' pjata/pjaty (поль пята/nяты; 41⁄2) еtc. (cf. Černyh 1994:54).

\section{5. 'HUNDRED', 'THOUSAND':}

The examination of the PIE numeral *kmtóm 'one hundred' led to discerning two main European branches: the centum and the satem branch. In the former group, the initial $\hat{k}$ - was hardened and blended with $* k$-, whereas in the latter group it shifted into an affricative or even a fricative. The Germanic branch belongs to the former group, whereas Slavic languages belong to the latter (compare Pol. sto, Rus. sto (cmo); cf. Jagodziński 2008).

- hundrede/hundred 'hundred': from the PIE form *dkmtóm (meaning originally 'tenth ten') simplified to *kmtóm - the initial $d$ - disappeared, but can still be as a glottal stop e.g. in Gr. hekatón (cf. Fortson 2004:131; Beekes 1995:213). It is worth mentioning that apart from the continuation of the PIE form there are also innovative Germanic forms to be found interpreted as 'tenty', e.g. Goth. 
taihuntehund or OHG zëhanzo/zëhanzug (cf. Blažek 1999:30), which also appear in O.D. among the G-type formations e.g. femsynnatyffwae, femsynnomtiwffwe (cf. Ross \& Berns 1992:619). Other forms such as hundrath, hundratth are explained from the stem *-roda, which originates from the P.Gmc. *rada-nta (cf. Ross \& Berns 1992:620). What is also interesting is the fact that the Old Norse hundrað may also mean 120 and is then called great (big, long) hundred (stórt hundrað), which again proves that Germanic cultures perceived 12 (together with 11 ) as a primary number and used it for counting various trading commodities (cf. Goodare 1993:395ff.). The big hundred may also be found (however with some irregularities concerning its use) in English, German (always as großhundert 'great hundred'), Frisian, Gothic and the Nordic languages (cf. Mengden 2013:4).

All higher hundreds are not represented by any common forms in PIE descendant languages. To express these numbers, different means are used, e.g. Goth. prija hunda 'three hundred', compounds such as Lat. trēcentī, or a collective as in O.Lat. sescentum 'a unit of six hundred' (cf. Beekes 1995:213).

- tusinde/tusind 'thousand': PIE * g $^{h} e s-l$-. There are several forms of 'thousand' in Indo-European languages, but it is impossible to reconstruct a common one for the Germanic, Baltic and Slavic group, hence alternative constructions had to be proposed. As far as the Germanic reconstruction is concerned, one of the suggested forms is *tusokmtī meaning 'strong hundred' that evolved into the

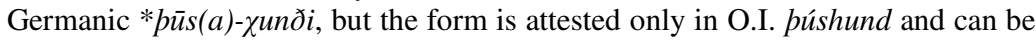
compared to the O.S. púshundrað The other suggested forms are *tū $(s / t)$-sñt-/sont-/-sent- meaning 'thick-being' or *tūs-nt-/-ont-/-ent- (from the root *tūs- 'to swell') that can be found in O.D. thusandlthusend (cf. Blažek 1999:315). Compare Ger. tausend, Dut. duizend, Pol. tysiac, Rus. tysjača (mысяча).

All the Germanic numbers above 'thousand' are borrowed from French (cf. Ross \& Berns 1992:632f.).

\subsection{UNITS OF MEASUREMENT}

One of the many and diverse uses of a counting system pertains to various trading goods that usually were packed in bundles containing a specific number or amount of the merchandise, which were referred to with help of different units of quantity. Therefore, apart from the "regular" decimal and vigesimal numerals found in the analysed series, there are also other ones in the language as in the case of the already mentioned score. In this case, Danish displays a combination of decimal, vigesimal, base-12 (duodecimal) and base-6 (sexagesismal) systems:

- deger 'dicker' = 10: from Lat. decuria derived from decem. Compare Ger. Decker (cf. ODS). The unit was usually used for large animal skins or hides, for smaller skins zimmer (simmer) $=40$ : from Ger. Zimmer; 
- $\quad$ dusin 'dozen' = 12: often while giving an approximate amount; O.D. dosin (cf. ODS) from $d u / s+i n \leftarrow$ French douzaine $\leftarrow$ derived from douze 'twelve' $\leftarrow$ Latin duodecim (...) 'twelve', actually 'two and ten' (compare december, duo; BeckerChristensen 1999). Compare Ger. Dutzend, Dut. dozijn, It. dozzina Pol. tuzin, Rus. djužina (дюжина);

- tylvt 'dozen' = 12: used only when referring to timber, from O.N. tylft 'amount of twelve';

- $\quad$ snes 'score' = 20: often used while giving an approximate amount, is a common Germanic word for counting related to the verb snide 'to cut'. The original meaning was 'a cut off branch' and therefore 'the number of items on the branch' (cf. Becker- Christensen 1999). See also 2.3. in this article;

- $\quad$ skok 'sixty': i.e. tre snese 'three score' from P.Gmc. *skukka- (cf.: OED), today usually used in the meaning 'a large amount of things', but also dialectically for counting sheaves (cf. ODS). Compare Engl. shock, Ger. Schock;

- $\quad$ ol 'eighty': i.e. fire snese 'four score', from O.N. völr, Got. walus (cf. DDO) usually used for counting eggs or herrings, is a is a common Germanic word originally referring to a rod or a stick that could hold eighty herrings (cf. BeckerChristensen 1999);

- gros 'gross' = 144: an abbreviated French form douzaine grosse meaning 'large dozen' from Lat. grossus 'large, thick' (cf. Becker-Christensen 1999). Compare Eng. gross, Ger. Gros, Dut. gros, Pol. gros, Rus. gross (zpocc);

- $\quad$ balle 'bale' = this unit refers to sheets of paper, but the amount it denotes depends on the paper type: 4000 sheets of waste paper or filter paper, 4800 sheets of writing or blotting paper, 5000 sheets of printing paper (cf. Blangstrup 1915:577).

As we can see, snes, skok and $o l$ can also be treated as yet another piece of evidence for traces of the vigesimal system not only in Danish but also other languages, which leads us to the conclusion that the "regular" counting system was supplemented by these forms when specific items, mainly various goods, were concerned.

Moreover, as we could see earlier, the Germanic languages form the numbers ' 11 ' and ' 12 ' in a completely different manner (by adding '-lif') than the following numbers, which are formed by adding '-teen' (cf. 3.2.). The break between these numbers seems to be a trace of a duodecimal counting (as seen above in dusin, tylvt, gros, balle), whose relics may still be found in other languages often combined with the sexagesimal system 12 months in a year, 24 hours $(12 \times 2)$ in a day, 60 minutes in one hour etc. (cf. Mengden 2013:5).

\subsection{LANGUAGE REFORMS}

In order to simplify the numeral system and support efficient communication between the language users in the Nordic community various reform bills were introduced by the Danish and Norwegian ministries. These bills are presented briefly in the following paragraphs. 
The Danish numerals pose a great challenge not only to those who learn Danish, but to the other members of the Nordic language community as well, for they are completely different from the ones found in Swedish, Norwegian and other European languages, Therefore, in 1948 an initiative to change the compound numeral forms and the order of their components ${ }^{10}$ was introduced as a part of a spelling reform. For example, femogtres 'sixty-five' would be sekstifem. The debate concerned only the cardinal numbers, but it was pointed out that such a change should affect the ordinals and fractions as well (cf. Karker 1959:7). As a result, following forms of the series 30-90 were proposed treti, firti, femti, seksti, syvti, otti, niti ${ }^{11}$ (cf. Karker 1959:10). These forms may lead one to think that they were created on the basis of the numbers found in Swedish and Norwegian, but the fact is that they are not only original but historically even older than the vigesimal numerals (which eventually dominated the more common Germanic forms). The decimal forms appear in written texts in every century, but rather sporadically and, especially after the Middle Ages, mainly as poetic variants (cf. Karker 1959:25ff.). Until 1870 dictionaries perceived them as being Norwegian. However, the survival of the decimal forms was secured - on one hand by, the language purist movement in Scandinavia (ca. 1870), on the other hand, by their usage in mercantile language since the monetary reform in 1875 (cf. ibid 10f.). After 1870 the decimal forms began to appear in the official spelling dictionary, but only until 1904, when they disappeared until 1955, although still appearing in other, even smaller dictionaries.

However, the notion was initially rejected by the Minister of Education who claimed that such change lies beyond the scope of orthography and the postal service (that accepted both variants in 1889). In 1957 a 50-crowns bill was issued bearing the inscription femti kroner, but even though some other attempts were made the system remained unchanged, whereas the proposed numerals are very rarely used - mainly on cheques or other official documents (cf. Jacobsen 2005:1964).

Faroese numerals of the series bear strong resemblance to the Danish ones (cf. 3.4.), and though they are the dominating forms, decimal numerals were also introduced but are used mainly in official correspondence and have only recently been adopted in broadcasting (cf.

${ }^{10}$ English, Norwegian, Swedish and Icelandic do not reverse the numerals, neither does modern English, although there may be numerous instances of it doing so, as in a well-known nursery rhyme "Sing a song of a sixpence": Sing a song of sixpence, / A pocket full of rye. / Four and twenty blackbirds, / Baked in a pie.

${ }^{11}$ These are not the only forms of the decimal numerals but the most common ones (for all the variants see Karker 1959:33ff.). 
Lockwood 2002:64). These forms are fimmti (50), seksti (60), sjeyti (70), áttati (80), and níti (90).

In Norway a bill was passed in 1951 in which it was stated that the tens should come before the units, but since there is no official spoken norm in Norway, this was a very unique political measure enforcing a specified change not only in the written but also the spoken language. The results of the enforcement were initially rather poor, for the numerals could only be heard in the media and, though less frequently, in official situations (cf. Vinje 1991:2f.). However, this changed in the early 1990s, and an increased usage of the new numeral forms can be observed not only among young but also older Norwegians. Nevertheless, both systems are applied simultaneously, the new one used chiefly while counting, the older one when referring to date or age (cf. Akselberg 2005:1825).

A similar reform attempts can also be observed in German - there is a movement called Zwanzigeins ('twenty one' as opposed to the regular einundzwanzig literally meaning, as in Danish, 'one and twenty).

\section{SUMMARY}

In the article Danish numerals 1-1000 as well as some Indo-European background for their description were presented. The possibilities of reconstruction of PIE numerals and the counting systems that appear in its daughter languages were also discussed. Among these the ten-based system (the decimal system) found most widely in all the Indo-European languages and the twenty-based system (the vigesimal system) found in Danish and some other modern and old European languages were described. The numerals 1-40 were shortly discussed by giving their PIE, Proto-Germanic and Old Danish forms supporting them by some additional formation about their development and similar forms in other languages. Thereafter, the focus was placed on the vigesimal forms of the numeral series 50-90 by giving an explanation of the system they apply, and their possible origin and spread form Eastern to Western Denmark that can be followed on the basis of texts dating back even to the Middle Ages.

As we could see, where the numerals of the lower series 1-40 are concerned, Danish is a fairly standard Germanic language applying the same system that is found in all the other languages of the Germanic branch. On the other hand though, the decades of the series 50-90 are quite baffling due to two reasons: firstly, it is extremely hard to attest their origin, secondly, they apply a multiplication structure involving the fractions $2 \frac{1}{2}, 3^{1 / 2}$ and $4 \frac{1}{2}$ (that can also be found in e.g. German and, in some extent, other languages) and the number twenty, thus rendering the system vigesimal. 
However, this state of affairs should not make one think that this system is absolutely unique and restricted only to Danish, for, as it was shown, despite the fact that the decimal system is undoubtedly dominant, traces of the vigesimal system can also be found in other modern IndoEuropean languages (although this path of development is rather peripheral), which is shown in the table below:

\begin{tabular}{|c|c|}
\hline Decimal only (examples) & Decimal and vigesimal \\
\hline Czech, Dutch, English, German, & Albanian, Breton, Danish, Faroese, \\
Greek, Icelandic, Italian, Latvian, & French, \\
Lithuanian, Norwegian, Polish, & Irish (seldom), Scottish Gaelic, \\
$\begin{array}{c}\text { Portuguese, Romanian, Russian, } \\
\text { Slovak, Spanish, Swedish }\end{array}$ & Slovenian (regional dialect), Welsh \\
\hline
\end{tabular}

(Fig 2.) Languages with the decimal only and combined decimal and vigesimal counting system

The vigesimal system can be though observed not only in the numeral system but also in some units of measurement (e.g. snes, skok, balle) that are applied by languages, in which the vigesimal system is non-existent and the vigesimal based units were adopted mainly due to trading affairs (e.g. Dutch, English, German, Norwegian, Swedish).

The traces of the vigesimal system in Danish has been a source of difficulties for other Scandinavians, but even though substitute forms similar to other Nordic languages were proposed as a part of a language reform initiative they were initially rejected by the government and the post office. Their status changed with time, and they now do appear on cheques, other official documents or in everyday communication between Scandinavians. However, they occur very sporadically and have not gained any ground in daily speech among the Danish speakers, quite unlike Norwegian, where two systems are now merged and used simultaneously (especially in speech), or Faroese, though in much lesser extent.

Further research in the matter could comprise an analysis of medieval and later texts containing the vigesimal numerals. This may be conducted in order to indicate the period in which these numerals replace the decimal forms, where the changes take place, what is their origin, and how they spread into Western Denmark, finally to become the dominant forms in the language.

\section{ABBREVIATIONS}

$\begin{array}{ll}\text { Dan. } & \text { Danish } \\ \text { DDO } & \text { Den Danske Ordbog (see References) } \\ \text { Dut. } & \text { Dutch }\end{array}$




$\begin{array}{ll}\text { Eng. } & \text { English } \\ \text { Fr. } & \text { French } \\ \text { Ger. } & \text { German } \\ \text { Got. } & \text { Gothic } \\ \text { Gr. } & \text { Greek } \\ \text { It. } & \text { Italian } \\ \text { Lat. } & \text { Latin } \\ \text { M.D. } & \text { Middle Danish } \\ \text { M.E. } & \text { Middle English } \\ \text { MHG } & \text { Middle High German } \\ \text { O.D. } & \text { Old Danish } \\ \text { O.E. } & \text { Old English } \\ \text { O.I. } & \text { Old Icelandic } \\ \text { O.Lat. } & \text { Old Latin } \\ \text { O.N. } & \text { Old Norse } \\ \text { O.S. } & \text { Old Swedish } \\ \text { OCS } & \text { Old Church Slavonic } \\ \text { ODS } & \text { Ordbog over det danske Sprog (see Rererences) } \\ \text { OED } & \text { Online Etymology Dictionary (see References) } \\ \text { OEN } & \text { Old East Norse } \\ \text { OHG } & \text { Old High German } \\ \text { P.Gmc } & \text { Proto-Germanic } \\ \text { P.N. } & \text { Proto-Norse } \\ \text { PIE } & \text { Proto-Indo-European } \\ \text { Pol. } & \text { Polish } \\ \text { Rus. } & \text { Russian } \\ & \end{array}$

\section{REFERENCES}

Akselberg, Gunnstein. 2005. Trends in the linguistic development since 1945, III: Norwegian. In: Bandle, Oskar et. al (eds.). The Nordic languages an international handbook of the history of the North Germanic languages, Vol. 2. Berlin: Mouton de Gruyter, pp. 1823-1831.

Bańkowski, Andrzej. 2000. Etymologiczny stownik języka polskiego. Tom 2. Warszawa: Wydawnictwo Naukowe PWN.

Becker-Christensen, Christian. 1999. Politikens Nudansk Ordbog med etymologi. København: Politiken.

Beekes, Robert S. P. 1995. Comparative Indo-European Linguistics. An Introduction. Amsterdam/Philadelphia: John Benjamins Publishing Company.

Blangstrup, Christian (ed.). 1915. Salmonsens Konversationsleksikon. Copenhagen: Schultz.

Blažek, Václav. 1999. Numerals. Comparative-etymological analyses of numerical systems and their implications. Brno: Masarykova Univerzita.

Boryś, Wiesław. 2005. Stownik etymologiczny języka polskiego. Kraków: Wydawnictwo Literackie.

Brøndum-Nielsen, Johannes. 1950-1957. Gammeldansk grammatik i sproghistorisk fremstilling. 1. Indledning. Tekstkildernes lydbetegnelse. Vokalisme. 2. Konsonantisme. 2nd, rev.ed. Copenhagen: Schultz.

Buck, Carl D. 1949. A dictionary of selected synonyms in the principal Indo-European languages. Chicago: University of Chicago Press. 
Černyh, Pavel Jakovlevič. 1994. Istoriko-etimologičeskij slovar' sovremennogo russkogo jazyka (Историко-этимологический словарь современного русского языка), Vol. 1. Moscow: Russkij jazyk.

Eliasson, Stig. 2006. Old Danish vigesimal counting: A comparison with Basque. In: Hornscheidt, Antje et al. (Hg.): Grenzgänger. Festschrift zum 65. Geburtstag von Jurij Kusmenko. Berlin: Nordeuropa-Institut, 1, pp. 91-110.

Fortson, Benjamin W. 2004. Indo-European Language and Culture: An Introduction. Malden-Oxford: Blackwell Publishing.

Gamkrelidze, Thomas V. \& Vjaceslav V. Ivanov. 1995. Indo-European and the IndoEuropeans: A Reconstruction and Historical Analysis of a Proto-Language and a Proto-Culture. Berlin/New York: Mouton de Gruyter.

Grimm, Jacob \& Wilhelm Grimm. 1854. Deutsches Wörterbuch. Band 1. Leipzig: S. Hirzel.

Gvozdanović, Jadranka. 1992. Remarks on numeral systems. In: Gvozdanović, Jadranka (ed.): Indo-European Numerals. Berlin/New York: Mouton de Gruyter, pp. 1-10.

Hurford, James R. 1975. The linguistic theory of numerals. Cambridge: Cambridge University Press.

Jacobsen, Henrik Galberg. 2005. Language cultivation and language planning, I: Denmark. In: Bandle, Oskar et al. (eds.): The Nordic Languages: An International Handbook of the History of the North Germanic Languages, Vol. 2. Berlin: Walter de Gruyter, pp. 1960-1969.

Karker, Allan. 1959. Nordiske talord i dansk. Copenhagen: Gyldendal.

Kluge, Friedrich. 1999. Etymologisches Wörterbuch der deutschen Sprache. Berlin/New York: Walter de Gruyter.

Lockwood, William Burley. 2002. An Introduction to Modern Faroese. Tórshavn: Føroya Skúlabókagrunnur.

Magnussen, Kristin. 2009. Sprog i fokus: Færøsk. In: Hällström-Reijonen, Charlotta af (ed.): Språk i Norden 2009: tema: språkpolitik och språkattityder. Copenhagen: Nordisk sprogkoordination, pp. 251-258.

Mańczak, Witold. 1985. Indo-European numerals and the sexagesimal system. Papers from the $6^{\text {th }}$ International Conference on Historical Linguistics, pp. 347-352.

Nielsen, Niels Åge. 1966. Dansk etymologisk Ordbog. Copenhagen: Gyldendal.

Noreen, Adolf. 1923. Altnordische Grammatik 1: Altisländische und altnorwegische Grammatik (Laut- und Flexionslehre) unter Berücksichtigung des Urnordischen. Halle: Niemeyer.

Pisani, Vittore \& Julius Pokorny. 1953. Allgemeine und vergleichende Sprachwissenschaft Indogermanistik. Bern: A. Francke Verlag.

Ross, Alan S. C. \& Jan Berns. 1992. Germanic. In: Gvozdanović, Jadranka (ed.): IndoEuropean Numerals. Berlin/New York: Mouton de Gruyter, pp. 555-715.

Venås, Kjell. 1990. Norsk grammatikk. Nynorsk. Oslo: Universitetsforlaget.

Vennemann, Theo \& Patrizia Noel Aziz Hanna (eds.). 2003. Europa Vasconica - Europa Semitica. Berlin/New York: Mouton de Gruyter.

Vinje, Finn-Erik. 1991. Om å få folk till å telle annerledes, Språknytt 4/1991, pp. 2-5.

Winter, Werner. 1992. Some thoughts about Indo-European numerals. In: Gvozdanović, Jadranka (ed.): Indo-European Numerals. Berlin/New York: Mouton de Gruyter, pp. 11-28. 


\section{INTERNET SOURCES}

Czesak, Artur. 2005. Wpót do dziewiatej. http://goo.gl/tuCZMt (15.09.2014)

Den Danske Ordbog http://ordnet.dk/ddo (15.09.2014)

Goodare, Julian. 1993. The long hundred in medieval and early modern Scotland. http://goo.gl/PU5TBx (15.09.2014)

Jagodziński, Grzegorz. 2008. Etymology of numerals. http://goo.gl/3bHGtF (15.09.2014)

Mengden, Ferdinand von. 2013. How Myths Persist: Jacob Grimm, the Long Hundred, and Duodecimal Counting. http://goo.gl/L4nohx (15.09.2014)

Online Etymology Dictionary. http://www.etymonline.com (15.09.2014)

Ordbog over det danske Sprog http://ordnet.dk/ods (15.09.2014)

\section{Błażej Garczyński}

Uniwersytet im. Adama Mickiewicza w Poznaniu

Katedra Skandynawistyki

Collegium Novum

al. Niepodległości 4

61-874 Poznań

Poland

blazej.garczynski@amu.edu.pl 